\title{
ТЕРМІНИ КОМП'ЮТЕРНОЇ СФЕРИ В РІЗНИХ МОВАХ: ГЛОБАЛІЗАЦІЙНІ ПРОЦЕСИ
}

\author{
ОЛЕНА ГАВРИЛОВА \\ Харківський національний педагогічний університет імені Г. С. Сковороди, \\ Харків - Україна \\ jelena8673@gmail.com; ORCID: 0000-0001-9450-9147 \\ TERMINY KOMPUTEROWE W RÓŻNYCH JĘZYKACH: \\ PROCESY GLOBALIZACYJNE \\ OLENA HAWRYŁOWA \\ Charkowski Narodowy Uniwersytet Pedagogiczny imienia Hryhorija Skoworody, \\ Charków - Ukraina
}

STRESZCZENIE. Artykuł analizuje wpływ światowych procesów globalizacyjnych w dziedzinie technologii komputerowych na różne języki. Pokazano metody uzupełniania terminologii komputerowej poprzez zapożyczenia z języka angielskiego i tworzenie owej leksyki za pomocą tłumaczenia. Analizowany jest wpływ procesu globalizacji na język ukraiński. W artykule przedstawiono ocenę wpływu innych języków, zwłaszcza rosyjskiego i angielskiego na język ukraiński.

Słowa kluczowe: proces globalizacji, terminologia komputerowa, języki, zapożyczenia, terminy, urządzenia, leksykon.

\section{TERMS OF COMPUTER SPHERE IN DIFFERENT LANGUAGES: GLOBALIZATION PROCESSES}

\section{OLENA HAVRYLOVA}

H. S. Skovoroda Kharkiv National Pedagogical University, Kharkiv — Ukraine

ABSTRACT. The influence of world globalization processes in the field of computer technologies on different languages has been considered in the article. The methods of replenishing the languages terminology due to the borrowings from the English language and creating computer terms with the help of translation have been shown. The influence of the globalization process on the Ukrainian language has been analyzed. The assessment of the other languages influences especially Russian and English on the Ukrainian language has been given in the article.

Key words: globalization process, computer terminology, languages, borrowings, terms, devices, lexis.

П

очинаючи від останніх десятиліть XX ст., майже всі народи та їхні культури зазнають впливу потужного світового процесу, який дістав назву “глобалізація". Глобалізація опиняється в центрі уваги не лише політиків й економістів, а й філософів, соціологів, культурологів, письменників, мовознавців. Термін глобалізація (від франц. global — 'загальний', 'всесвітній') був уведений у науковий обіг у сер. 80-х років XX ст. американськими вченими, які позначили ним появу нового типу соціальності й світового порядку, що буквально за всіма формами й параметрами відрізнявся від нині існуючого. Появу цього терміна пов'язують з ім'ям Теодора Левіта, який у статті, опубліко- 
ваній 1983 р., позначив терміном глобалізація факт злиття ринків окремих продуктів, вироблених великими багатонаціональними корпораціями. Поширення цей термін отримав завдяки дослідженням англійського соціолога Р. Робертсона та японського фахівця в галузі стратегічного менеджменту К. Омає, який опублікував бестселер Світ без кордонів (1990). Існує багато концепцій і підходів до визначення того, що розуміти під глобалізацією, які аспекти та сфери вона охоплює. Глобалізація є найбільш дискусійною й водночас найменш зрозумілою тенденцією сучасного світу. Нині глобалізаційні процеси охопили всі сфери життя людства й мають прямий чи опосередкований вплив на економіку, політику, культуру, мову країн світу. Особливої уваги потребує національна мова й той факт, що глобалізація вносить суттєві корективи в мову, оскільки вона як основний засіб спілкування перша відчуває всі зміни глобалізаційних процесів.

У науковому світі існує чимало публікацій, у яких у різних аспектах висвітлюються проблеми взаємного впливу суспільства й мови. Феномен глобалізації, що відображений у мові, активно досліджують учені, зокрема такі, як Б. Ажнюк, Т. Возняк, А. Панарін, В. Радчук та інші, оскільки ця проблема стає все більш актуальною.

Мову як засіб комунікації традиційно вважають одним з основних індикаторів стану суспільства загалом, тому всі трансформації суспільних відносин передусім виявляються в мовному середовищі. Наприкінці XX ст. був зроблений великий стрибок у розвитку науково-інформаційних технологій, передусім у сфері комп'ютерних та телекомунікаційних мереж, що дало змогу відповідно спілкуватися, отримувати інформацію, яка поширюється по всій земній кулі й відбувається в будь-який час. Якщо раніше зв'язок з людьми з інших країн був можливий тільки за допомогою телефонів, листів, телеграм, то, завдяки процесу глобалізації, спілкування стало можливим і в режимі реального часу. Як зазначив В. Алпатов, „прагнучи до економічного єднання світу, глобалізація викликає тенденцію до його мовного єднання"'.

Функціонування мов зазнає значних змін у зв'язку з процесами глобалізації. Однак якщо раніше ці зміни в усіх сферах виявлялися переважно в межах однієї держави, то протягом кількох останніх десятиліть вони стали проявлятися на рівні світового лінгвістичного процесу. Найвиразніше цей процес виявляється в термінології, якою послуговується наука, техніка, мистецтво й інші галузі, пов'язані з людською діяльністю й активним пізнанням світу.

Світовими мовами, що відомо, є мови, прийняті як робочі мови міжнародних громадських організацій, ті, що поширені в різних сферах спілкування між людьми різних мовних спільнот (англійська, французька, китайська, російська, іспанська й арабська). Кожна з них тривалий час мала власний мовний простір, але інтенсивна глобалізація спричинила посилення конкуренції між світовими мовами. Усе частіше ми стикаємося із ситуацією, коли сучасні інформаційні технології базуються виключно на матеріалі англійської мови. На міжнародних наукових конференціях усі доповіді читають і публікують англійською, міжнародні переговори ведуться також виключно англійською. Англійська мова поширюється передусім як загальна друга мова. Leo Loveday визначив, що „ряд сфер майже цілком відданий американізмам, які складають $53 \%$ термінів менеджменту, $75 \%$ термінів маркетингу, 80 \% торгових термінів і навіть $99 \%$

${ }^{1}$ В. Алпатов, Глобализация и развитие языка, [в:] „Вопросы филологии”, Москва 2004, № 2, c. 23-27. 
комп’ютерної термінології’2. Ці терміни набувають статусу інтернаціональних, засвідчуючи інтернаціоналізацію певних розрядів лексики.

Щорічно 3'являються нові види пристроїв (нетбук, смартфон, комунікатор i т. д.) і типи зв'язку (портали, форуми, чати, блоги і т. д.) 3 метою полегшити й прискорити процес комунікації. 3 появою новинок у сфері інформаційних технологій відбувається оновлення комп'ютерної термінологічної лексики: створюються нові й трансформуються вже існуючі термінологічні одиниці.

У 1971 році компанія “Intel” створила перший комп’ютерний чіп. Це стало початком другої технологічної революції, що спричинила створення персональних комп'ютерів п'ятого покоління. 31973 року розпочалася ера стільникових телефонів. У 1990 році в Свропейській фізичній лабораторії CERN був створений протокол - www - World Wide Web i протягом року Інтернет почав діяти більш ніж у 30 країнах світу. До мережі отримали доступ більше 4 мільйонів чоловік. У 2000 році кількість інтернет-серверів збільшилась на 44 \%, у світі додалося 80 мільйонів користувачів Усесвітньої мережі. Через 2 роки мережа Інтернет зв'язала 689 мільйонів користувачів, а ще через рік у світі нараховувалося більше 3 мільярдів інтернет-сайтів. Сучасне мовне середовище почало активно використовувати англомовну лексику для поповнення термінологічного запасу. Переважно це пов'язане або з відсутністю понять, що позначають англійські терміни в мові-реципієнті, або із громіздкими, незручними для використання термінологічними словосполученнями, що описують ці явища.

В українській науці з'явилося чимало праць, у яких розглядаються загальні теоретичні питання термінознавства, а також аналізуються різні галузеві термінології й терміносистеми. Це, зокрема, перший в українському науковому обігу підручник Т. Панько, І. Кочан, Г. Мацюк Украӥнське термінознавство, колективна монографія А. Д'якова, Т. Кияка, 3. Куделько Основи термінотворення: семантичні та соціолінгвістичні аспекти, дослідження М. Годованої, Т. Кияка, I. Кочан, Л. Мурашко, Л. Полюги, О. Тараненка, Я. Януш та інших учених, друковані в наукових збірниках і періодичних виданнях. Питання іншомовних запозичень у сучасній українській термінології в центрі уваги публікацій С. Снікеєвої, Т. Лещука, Л. Симоненко, Г. Наконечної, Н. Томілової та ін.

Отже, наслідками глобалізації $€$ зростання ролі англійської мови в неангломовних країнах і проникнення iï в різні шари лексики. 3 одного боку, це сприяє науково-технічному прогресу, оскільки заповнює порожні місця в термінології. 3 іншого - спричиняє появу суржикових конструкцій, особливо в журналістів або фахівців у сфері комп’ютерних технологій, що засмічує літературну мову.

Тривалий час українська термінологія поповнювалася за рахунок російських термінів. Деякі з українських термінів були скальковані 3 російської мови i, якщо їхній морфемний склад не суперечив будові українського слова, стали широко використовуватися нарівні зі словами української мови. Англомовні терміни опція, сервер, файл та под. проникли у свідомість користувача комп'ютерної техніки.

Шляхи й способи утворення комп'ютерної лексики дуже різноманітні. Але всі вони зводяться до того, щоб пристосувати англійське слово до дійсності й зробити його придатним для постійного використання. Порівняємо деякі терміни, що використовуються на позначення технічних пристроїв та частин цих пристроїв у різних мовах:

${ }^{2}$ L. Loveday, Language Contact in Japan, [in:] A social-Linguistic History, Oxford 1996, pg. 101-103. 


\begin{tabular}{|c|c|c|c|c|}
\hline Англ. & Укр. & Рос. & Польск. & Нім. \\
\hline computer & комп'ютер & компьютер & komputer & Computer \\
\hline printer & принтер & принтер & drukarka & Drucker \\
\hline scanner & сканер & сканер & skaner & Scanner \\
\hline хеrox & ксерокс & ксерокс & ksero & Xerox \\
\hline disk & диск & диск & dysk & Disk \\
\hline $\begin{array}{c}\text { display } \\
\text { monitor }\end{array}$ & $\begin{array}{c}\text { дисплей } \\
\text { монітор }\end{array}$ & $\begin{array}{c}\text { дисплей } \\
\text { монитор }\end{array}$ & $\begin{array}{c}\text { wyświetlacz } \\
\text { monitor }\end{array}$ & $\begin{array}{c}\text { Display } \\
\text { Bildschirm }\end{array}$ \\
\hline router & роутер & роутер & router & Router \\
\hline slot & слот & слот & gniazdo & Slot \\
\hline toner & тонер & тонер & toner & Toner \\
\hline $\begin{array}{c}\text { notebook } \\
\text { laptop }\end{array}$ & ноутбук & ноутбук & laptop & Laptop \\
\hline
\end{tabular}

Зауважимо, що більшість сучасних словників й енциклопедій визначає слова laptop і notebook як синоніми. Обидві ці назви використовуються для позначення портативного комп'ютера невеликої ваги, у корпус якого вмонтовані клавіатура й дисплей. У дослівному перекладі laptop - це 'комп'ютер, який можна розмістити на власних колінах (на відміну від desktop - настільного ПК)' Notebook - це 'пристрій, що розкривається подібно до зошита'. В умовах сучасного ринку електроніки відмінність між термінами laptop і notebook остаточно нейтралізувалася.

Уважають, що категорія laptop включає ноутбуки, нетбуки, ультрабуки, смартбуки й трансформери. Такої думки дотримуються англомовні споживачі, які не уточнюють вид ПК без технічної необхідності. Українськомовні користувачі так само одним терміном notebook називають усі перераховані типи.

Отже, сучасні терміни laptop та notebook - одне й те саме, але по різні боки кордонів. В англійській мові notebook використовується нечасто через омонімічність: це слово позначає блокнот, зошит. Англомовні користувачі надають перевагу терміну laptop, українськомовні та російськомовні - ноутбук.

Як бачимо, українська та російська мови повністю копіюють назву англійського терміна, а в німецькій та польській мовах 3'являється переклад, створений з власного мовного матеріалу.

Не завжди в українську комп'ютерну лексику потрапляють слова, запозичені з англійської мови. Часто англійський термін або його частину перекладають українською мовою стилістично нейтральними словами, а інша частина залишається без змін.

\begin{tabular}{|c|c|c|c|c|}
\hline Англ. & Укр. & Рос. & Польск. & Нім. \\
\hline start page & $\begin{array}{c}\text { стартова } \\
\text { сторінка }\end{array}$ & $\begin{array}{c}\text { стартовая } \\
\text { страница }\end{array}$ & $\begin{array}{c}\text { strona } \\
\text { startowa }\end{array}$ & Startseite \\
\hline
\end{tabular}


Терміни комп'ютерної сфери в різних мовах: глобалізаційні прочеси

\begin{tabular}{|c|c|c|c|c|}
\hline $\begin{array}{l}\text { archived } \\
\text { file }\end{array}$ & архівний файл & $\begin{array}{c}\text { архивный } \\
\text { файл }\end{array}$ & $\begin{array}{c}\text { plik } \\
\text { archiwum }\end{array}$ & Archivdatei \\
\hline $\begin{array}{l}\text { cache- } \\
\text { memory }\end{array}$ & кеш-пам'ять & кэш-память & $\begin{array}{l}\text { pamięć } \\
\text { cache }\end{array}$ & Cache-Speicher \\
\hline hard disk & жорсткий диск & $\begin{array}{l}\text { жесткий } \\
\text { диск }\end{array}$ & $\begin{array}{l}\text { twardy } \\
\text { dysk }\end{array}$ & Festplatte \\
\hline $\begin{array}{c}\text { control } \\
\text { panel }\end{array}$ & $\begin{array}{c}\text { панель } \\
\text { керування }\end{array}$ & $\begin{array}{c}\text { панель } \\
\text { управления }\end{array}$ & $\begin{array}{c}\text { panel } \\
\text { kontrolny }\end{array}$ & Bedienfeld \\
\hline $\begin{array}{l}\text { application } \\
\text { server }\end{array}$ & сервер додатків & $\begin{array}{c}\text { сервер } \\
\text { приложений }\end{array}$ & $\begin{array}{c}\text { serwer } \\
\text { aplikacji }\end{array}$ & $\begin{array}{l}\text { Anwendungs- } \\
\text { server }\end{array}$ \\
\hline hyperlink & гіперпосилання & гиперссылка & hiperlink & Hyperlink \\
\hline audio data & аудіодані & аудиоданные & dane audio & Audio-Daten \\
\hline $\begin{array}{l}\text { internal } \\
\text { modem }\end{array}$ & $\begin{array}{l}\text { внутрішній } \\
\text { модем }\end{array}$ & $\begin{array}{c}\text { внутренний } \\
\text { модем }\end{array}$ & $\begin{array}{c}\text { modem } \\
\text { wewnętrzny }\end{array}$ & $\begin{array}{l}\text { Internes } \\
\text { Modem }\end{array}$ \\
\hline mouse port & порт миші & порт мыши & port myszy & Mausanschluss \\
\hline
\end{tabular}

В українській та російській мовах у всіх наведених словосполученнях $\epsilon$ елемент перекладу й іншомовного вкраплення, найбільше винятків у німецькій мові, де використовують терміни, засновані на власному мовному матеріалі.

Лінгвісти часто ставлять за приклад арабську мову, тому що вона має найменшу кількість іншомовних украплень. Практично всі назви технічних пристроїв та їхніх частин мають власні арабські назви, не співвідносяться ні графічно, ні фонетично з англійськими аналогами. Але всі назви комп'ютерних програм, додатків, операційних систем тощо в усіх мовах фонетично й графічно відображаються мовою оригіналу (найчастіше це англійська). Напр.: Windows, Linux, Adobe Reader, Photoshop, Microsoft Word, Excel та інші вимовляються та пишуться виключно англійською мовою.

Отже, як бачимо, процес глобалізації відбувається надзвичайно енергійно. У результаті стрімкого розвитку телекомунікацій та інформаційних технологій усе розмаїття мов світу спочатку було практично зведено до шести світових мов: англійська, французька, іспанська, російська, китайська, арабська. У наш час безперечним лідером, що вже перемагає інші світові мови, виявляється англійська мова. Що стосується сучасної української мови, то вона зазнає впливу декількох потужних чинників. Першим 3 них все ще залишається російська мова, а другим - англійська. До речі, в Україні російську мову з багатьох сфер витісняє саме англійська. Чимало англіцизмів сьогодні витісняють з обігу українські й російські слова. Б. Ажнюк у статті Мовні зміни на тлі деколонізащії та глобалізації, аналізуючи наслідки заповнення функціональної ніші російської мови в Україні, зазначав, що глобалізаційні процеси спричиняють усе більшу присутність англійської мови в інформаційно-комунікативному просторі Україниㄱ. В іншій своїй роботі він зазначає, що „глобалізація загострює боротьбу за панування в інформаційному просторі. Йдеться не тільки про суперництво

${ }^{3}$ Б. Ажнюк, Мовні зміни на тлі деколонізачії та глобалізачїі, [в:] „Мовознавство”, Київ 2001, № 3, c. 48-54. 
між медіа-концернами, але й між національними мовами. На функціональну нішу російської мови в Україні дедалі більше претендує не тільки українська, але й англійська мови"'.

Відзначимо також, що вплив глобалізаційних процесів на розвиток і функціонування мов не обмежується лише розповсюдженням англіцизмів. Бурхливий розвиток віртуальної комунікації призводить до нехтування правилами орфографії й навіть граматики, напр., відсутність великих літер, пропусків артиклів тощо.

3 одного боку, уживання таких слів виправдане: вони є своєрідними товарними знаками, які не можна змінювати, оскільки їхня мовна форма зареєстрована, тобто, коли назва зареєстрована в латинській графіці як товарний знак, то в такому вигляді вона функціонує в усіх інших мовах. 3 другого боку, унаслідок впливу глобалізаційних процесів на розвиток національних мов слова й словосполучення англійської мови поступово витісняють питомі одиниці національної мови й заступають їх. Отже, англійська мова допомагає активізації процесу комунікації в усьому світі, що є особливо важливим у добу глобалізації, але тотальне використання англійської мови негативно позначається на лексиці інших національних мов.

\section{Список використаної літератури}

Ажнюк Б., Мовні зміни на тлі деколонізації та глобалізаиії, [в:] „Мовознавство”, Київ 2001, № 3, c. 48-54.

Ажнюк Б., Лінгвістичні аспекти глобалізаиії в Україні, [в:] Мовні конфлікти i гармонізаиія суспільства, матеріали наук. конфер. 28-25 травня 2001 року, Київ 2002, с. 144.

Алпатов В., Глобализация и развитие языка, [в:] „Вопросы филологии”, Москва 2004, № 2, c. 23-27.

Возняк Т., Семантичний простір мови. Тексти та переклади, Харків 1998.

Д’яков А., Кияк Т., Куделько З., Основи термінотворення: Семантичні та соиіолінгвістичні аспекти, Київ 2000.

Єнікеєва С., Особливості перекладу англійських комп'ютерних термінів на украйнську мову, [в:] „Вісник Сумського держ. ун-ту. Сер. «Філологічні науки»”, під ред. О. Г. Ткаченко, Суми 2001, № 5 (26), с. 54-59.

Космеда Т., Соболь Л., Графічні системи слов'янських мов: взаємовплив та прагматика, [в:] „Наукові праці, серія «Філологія. Мовознавство»”, Київ 2016, № 278, вип. 266, с. 63-67.

Лещук Т., Типологія термінологічних підсистем. Іншомовні запозичення, фразеологія, семантичні термінотворення, лексикографія: Монографічне дослідження на матеріалі німещької мови, Львів 1999.

Панько Т., Кочан І., Мацюк Г., Українське термінознавство, Львів 1994.

Радчук В., Плекаємо укрлиш... Для кого?, [в:] „Урок української”, 2003, № 8-9, с. 26-30.

Loveday L., Language Contact in Japan, [в:] A social-Linguistic History, Oxford 1996, pg. 101-103.

Mikhalchenko V., Trushkova Yu., Russian in the modern world, [in:] Language in a globalizing world, Cambridge 2003.

\footnotetext{
${ }^{4}$ Б. Ажнюк, Лінгвістичні аспекти глобалізачії в Україні, [в:] Мовні конфлікти і гармонізачія суспільства, матеріали наук. конфер. 28-25 травня 2001 року, Київ 2002, с. 144.
} 


\section{Spysok vykorystanoi literatury \\ [References]}

Azhniuk B., Movni zminy na tli dekolonizatsii ta hlobalizatsii [Language Changes on the Background of Decolonization and Globalization], [v:] „Movoznavstvo”, Kyiv 2001, № 3, s. 48-54.

Azhniuk B., Linhvistychni aspekty hlobalizatsii v Ukraini [Linguistic Aspects of Globalization in Ukraine], [v:] Movni konflikty $i$ harmonizatsiia suspilstva, materialy nauk. konfer. 28-25 travnia 2001 roku, Kyiv 2002, s. 144.

Alpatov V., Globalizaciya i razvitie yazyka [Globalization and Language Development], [v:] „Voprosy filologii”, Moskva 2004, № 2, s. 23-27.

Vozniak T., Semantychnyi prostir movy. Teksty ta pereklady [Semantic Language Space], Kharkiv 1998.

Diakov A., Kyiak T., Kudelko Z., Osnovy terminotvorennia: Semantychni ta sotsiolinhvistychni aspekty [Fundamentals of Term-Formation: Semantic and Socio-Linguistic Aspects], Kyiv 2000.

Yenikeieva S., Osoblyvosti perekladu anhliiskykh kompiuternykh terminiv na ukrainsku movu [Peculiarities of English Computer Terms Translation into Ukrainian], [v:] „Visnyk Sumskoho derzh. un-tu. Ser. «Filolohichni nauky»" pid. red. O. H. Tkachenko, Sumy 2001, № 5 (26), s. 54-59.

Kosmeda T., Sobol L., Hrafichni systemy slovianskykh mov: vzaiemovplyv ta prahmatyka [Graphic Systems of Slavic Languages: Mutual Influence and Pragmatics], [v:] „Naukovi pratsi, seriia «Filolohiia. Movoznavstvo»", Kyiv 2016, № 278, vyp. 266, s. 63-67.

Leshchuk T., Typolohiia terminolohichnykh pidsystem. Inshomovni zapozychennia, frazeolohiia, Semantychni terminotvorennia, leksykohrafia: Monohrafichne doslidzhennia na materiali nimetskoi movy [Typology of Terminological Subsystems. Foreign Borrowings, Phraseology, Semantic Term-Formation, Lexicography: Monographic Research based on the German Language], Lviv 1999.

Panko T., Kochan I., Matsiuk H., Ukrainske terminoznavstvo [Ukkrainian Terminology Studies], Lviv 1994.

Radchuk V., Plekaiemo ukrlysh... Dlia koho? [Caress ukrlysh... For whom?], [v:] „Urok ukrainskoi”, 2003, № 8-9, s. 26-30.

Loveday L., Language Contact in Japan, [v:] A Social-Linguistic History, Oxford 1996, pg. 101-103.

Mikhalchenko V., Trushkova Yu., Russian in the Modern World, [in:] Language in a globalizing world, Cambridge 2003. 